\title{
PENTECOSTAL HERMENEUTICS AND THE MARGINALISATION OF WOMEN
}

\author{
Rosinah Mmannana Gabaitse \\ Theology and Religious Studies \\ University of Botswana
}

\begin{abstract}
The Pentecostal movement remains one of ambivalence, tensions and paradoxes. On the surface, worship and practice appear democratic, yet research shows that women and men do not occupy the same status because the movement endorses male dominance and submission of women to men. While there is a sense that men and women are equal because both can receive the Spirit, women still remain in the margins. Sometimes women are affirmed and accepted because of the emancipatory role of the Spirit, but at other times they are marginalised through oppressive interpretative practices of the Bible. Although women are given voice, especially because of the belief within Pentecostal churches that the Holy Spirit speaks through men and women, the same voice is taken away when women are subordinated to male power. As such the Pentecostal space is ambivalent, although women are not completely silenced, they occupy a subordinate position. In this article I seek to demonstrate that the marginalisation of Pentecostal women is due to a considerable extent to the ways in which the Bible is read and interpreted within the Pentecostal tradition. I seek to demonstrate that there is a link between the marginalisation of women and Pentecostal hermeneutical strategies such as literal readings and prooftexting of the Bible. I will also highlight how the interpretation of the Trinity is also implicated in the marginalisation of women. In the final section of the article I will demonstrate how Pentecostals' openness to the work of the Holy Spirit should be a destabilising principle for all Pentecostals' oppressive activities, especially Pentecostal hermeneutics which tends to favour men over and above women.
\end{abstract}

Key Words: Pentecostalism; Bible; Interpretation; Marginalisation and Women

\section{Introduction}

Pentecostal communities foreground the Holy Spirit. The Holy Spirit is central to how they live and conduct their activities. The Holy Spirit is a power who speaks, defines, directs and frees individuals and Pentecostal communities. Further, the Holy Spirit is perceived as a participant and power that directs Pentecostal living. It is from this point of view that Pentecostals believe that it is through the Holy Spirit that women can minister during church services, they can prophesy, lay hands on the sick and they can be founders of churches, the same way men can. On the surface, it seems that Pentecostal women are free to be what the Holy Spirit says they can be and do. Moreover, Pentecostal women have freedom because they are not bound by laws that dictate, for example, that women should not minister when they have menstrual periods. Above this, Pentecostal women do not have dress restrictions, i.e. they can wear what they want and they do not have to cover their heads during worship if they do not want to. In short, they are not restricted by laws and taboos. Although they enjoy some of the above freedoms, they are marginalised because 
they must still submit to the authority of men both at home and in church. Although Pentecostal women can be filled with the Holy Spirit and have experiences parallel to those of men, Pentecostal women in Africa and elsewhere are subordinated to male power. Power and authority are understood and interpreted as the right of males and as such the status of women is pushed to the margins while men occupy the centre. This makes the Pentecostal space ambivalent because women are embraced and excluded at the same time. The marginal status of women is advanced and maintained through the use of the Bible and through interpretation of the same. Therefore, I seek to argue that there is a link between the marginalisation of women within Pentecostal churches and Pentecostal frames of reading the Bible.

\section{Pentecostalism and Ambivalence towards Women}

For decades now Pentecostalism has been celebrated as empowering women. Scholars of Pentecostalism such as Estrelda Alexander, Kwabena Asamoah-Gyadu and Ogbu Kalu positively celebrate the liberational potential of Pentecostal movement as it promises greater freedom than other branches of Christianity. Estrelda Alexander argues that women are attracted to Pentecostalism today because of its inherent promise of freedom to be fully involved in ministry. ${ }^{1}$ Similarly, Kalu argues that Pentecostal churches are gender friendly and open up more spaces for women than other church denominations. He argues that African Initiated Churches (AICs) still limit women's roles "by sourcing their gender ideology from traditional society." 2 Supporting this line of thought, Kwabena AsamoahGyadu argues that:

The charismatic ministries do not impose any Levitical or traditional taboos on women.

They regard these as being inconsistent with New Testament teachings particularly with the missionary experiences that followed the outpouring of the Holy Spirit in Acts. ${ }^{3}$

Recent studies indicate that while the Pentecostal movement is potentially a liberating space, ambivalent attitudes towards women still exist. The Pentecostal church remains a space which subjugates women "even as it offers them a unique permission to speak." For a long time scholars of Pentecostalism focused on the emancipatory role of the Holy Spirit, focusing on the fact that Pentecostal women can preach and teach under the infilling of the Holy Spirit. However, they paid little attention to the oppressive interpretative practices with regard to the Bible and the Pentecostals' patriarchal tendencies in general which support and uphold male power. Recent studies indicate that boundaries of exclusion exist along gender lines within the Pentecostal movement in Africa, ${ }^{4}$ Asia, ${ }^{5}$ and in the West. ${ }^{6}$ It is evident that women and men do not occupy the same status and Pentecostal churches

Alexander, E, “Introduction.” In Philip's Daughters: Women in Pentecostal-Charismatic Leadership, (eds.)

Estrelda Alexander and Amos Yong, Eugene, Oregon: Pickwick Publications, 2009:2-3.

2 Kalu, O African Pentecostalism: An Introduction. Oxford: Oxford University Press, 2008:149.

3 Asamoah-Gyadu, K, “'Fireballs in our Midst': West Africa Burgeoning Charismatic Churches and the Pastoral Role of Women," Mission Studies 15-16, no 296, 1998:21.

4 Masenya, M, How Worthy is the Woman of Worth: Rereading Proverbs 31:10-31 in African South Africa. Peter Lang: New York 2004:1-5; Nadar, S, “The Bible Says!" Feminism, Hermeneutics and Neo-Pentecostal Challenges' in Journal of Theology for Southern Africa Vol 134, (2009).

5 Tan-Chow, ML, Pentecostal Theology for the Twenty First Century: Engaging with Multi-Faith Singapore. Burlington: Ashgate Publishing Company, 2007:136-138.

6 Powers, JA, 'Recovering a Woman's Head with Prophetic Authority: A Pentecostal Reading of 1 Corinthians 11:3-16’ JPT 10.1 2001:27. 
remain patriarchal. Literature referred to above indicates that many Pentecostal churches are not only patriarchal, but they are resistant to gender transformation as well. Their theology propagates gender injustice and inequality by reinforcing male supremacy. The leadership model employed by Pentecostal churches has also been described as authoritarian and hierarchical, promoting male authority and hierarchical relationships with women and children at the bottom. The hierarchical relationships are promoted not only within the church context, but are promoted and encouraged within the family as well. All these are done through the use and interpretation of a few Biblical texts that seem to promote male power and submission of women to men.

Moreover, Pentecostalism does not promote the full dignity and rights of women in any radical way. Rekopantswe Mate captures this very well. She argues that Pentecostal churches are not doing much to destabilise or threaten patriarchy; rather patriarchy is reinforced through advancing teachings that call for female submission and the headship of the male. ${ }^{7}$ Female domesticity and subordination, the classic characteristics of patriarchy, are reinforced and maintained as Biblical and godly through the use of texts such as Ephesians 5:22-6:4, which if read uncritically may seem to support and advance patriarchal ideologies. By advancing female submission through the use of texts such as Ephesians 5:22-6:4, the Pentecostal church is not threatening patriarchal prerogatives, but rather patriarchal prerogatives are being enacted, kept alive and maintained. Failure to destabilise and threaten patriarchal prerogatives causes hermeneutical tensions within Pentecostal hermeneutics. When it comes to female subordination and male dominance, ambiguities arise within the Pentecostal movement in two major ways. First, although there is language and talk about equality between men and women because of the work of the Holy Spirit, that language is not put into actual practice as women remain at the periphery and at the bottom of the gender hierarchy. The Pentecostal church has failed to deconstruct texts that advance male power, so that men and women are truly equal. Second, while it is true that Pentecostal women and men can be filled with the Holy Spirit and have experiences that parallel the experience detailed in Acts 2, it is also true that Pentecostal frames of reading and interpreting the Bible insist that women must submit to men. Therefore, Pentecostal women are still located in spheres under male domination even when there is a claim that they too can receive the Holy Spirit. ${ }^{\mathbf{3}}$ Therefore, the marginalisation of women is mostly due to oppressive Pentecostal hermeneutics, especially the one practiced in churches.

\section{The Two Forms of Pentecostal Hermeneutics}

Pentecostal hermeneutics can be classified into two kinds, the "articulated Pentecostal hermeneutic and the unarticulated Pentecostal hermeneutics". Articulated Pentecostal hermeneutics refers to an academic exercise of reading and interpreting the Bible. Scholars of Pentecostalism are conscious of engaging in, developing and shaping this kind of hermeneutic. The desire to construct a Pentecostal hermeneutic arose because scholars of Pentecostalism such as Christopher Thomas were less content with "adopting a system of interpretation that is heavily slanted towards rationalism and has little room for the role of

Mate, R, "Wombs as God's Laboratories: Pentecostal Discourses on Femininity in Zimbabwe," Africa, Journal of the International African Institute 72, no. 4, 2002:566.

$8 \quad$ Yong, A, The Spirit Poured Out on All Flesh: Pentecostalism and the Possibility of Global Theology. Michigan: Baker Academic, 2005:40 
the Holy Spirit."9 This hermeneutic reflects on the tradition and ethos present within the Pentecostal tradition in order to appreciate the role of the Holy Spirit and religious experience in the interpretation of the Bible, yet it takes the principles of critical scholarship and biblical interpretation seriously. It has clear principles of interpretation, especially after Christopher Thomas and Kenneth Archer proposed a tridactic model of interpretation consisting of Scripture, Spirit and Community. ${ }^{10}$ The hermeneutic conforms to the principles of contemporary critical scholarship because it has to be compatible with academic rigour. As such, although the hermeneutic is Pentecostal, the Bible is read and interpreted critically, taking into consideration the context in which it was produced and the culture of the time, among other things.

Unarticulated Pentecostal hermeneutics on the other hand happens within a Pentecostal church community, in churches and in the pews. It is practiced, acted and performed in the churches as Pentecostal members are engaged in shaping and developing this hermeneutic. Unarticulated Pentecostal hermeneutics consists of the often unconscious hermeneutical strategies used by the community. Some, if not most, Pentecostal church members are not conscious that they are engaged in shaping and developing a hermeneutic as they participate in Pentecostal activities such as preaching, prayers, Bible studies, hymns and testimonies. Moreover, this is the kind of hermeneutic that is patently pre-critical in nature and it is characterised by taking and understanding the Bible at face value because it is not concerned with the contexts in which the Bible was produced. Most practitioners of this kind of hermeneutic do not always consider the history of the biblical text, the cultures which writers of the Bible inhabited and the agendas of the biblical writers. These details are not always important to them; "what is important is that the Bible is the Word of God," 11 and should be read and obeyed. Archer points out that this kind of hermeneutic as it is practiced in most churches places no significance on "the historical context of the text, the Bible is the Word of God and it is to be understood at face value."12 This hermeneutic, which tends to be uncritical towards texts in general, and especially texts that seem to support the marginalisation of women, is at the centre and focus of this article. Because of the uncritical reading of the Bible, texts calling women into submission are read and interpreted without taking the context in which they were produced into consideration. It does not matter that these texts were written by Paul within Greco-Roman imperial and patriarchal environments, these texts are applied as if they were written as laws that dictate and prescribe gender relations and the status of women in the $21^{\text {st }}$ century.

The two essential aspects of Pentecostal hermeneutics that have bearing on the marginalisation of women are literal interpretations of the Bible and proof texting of the Bible. In addition to these, I will describe how the theological category or Pentecostal doctrine of the Trinity (which is derived from the Bible) further contributes towards the marginalisation of women. This article draws from existing literature and from the

\footnotetext{
9 Thomas, C' "Women Pentecostals and the Bible: An Experiment in Pentecostal Hermeneutics." JPT 5, 1994:41-56.

10 Thomas, "Women, Pentecostals and the Bible"; also see K Archer, "Early Pentecostal Biblical Interpretation," JPT 18, 2001:67.

11 Archer, "Early Pentecostals Biblical Interpretation," 67

12 Archer, 'Early Pentecostals Biblical Interpretation', JPT 18, 2001:67.
} 
information I gathered when I conducted fieldwork in 2011. ${ }^{13}$ The information in this article is filtered through a feminist theoretical framework of analysis.

\section{Literal Readings of the Bible and the Marginalisation of Women}

One of the most dominant models of biblical interpretation in Pentecostal churches is the literal one. A literal reading of the Bible is the kind that takes the Bible at face value and uncritically, and claims that the "Bible says it and I believe it." A literal reading of the Bible does not take the historical context of texts seriously. The Bible is read in the present to mean what it means. The effects of literalism can be dangerous, especially in relation to the treatment of women and rules relating to their status. The commitment by Pentecostals in churches to take and interpret the Bible literally means that "scriptural directives that insist on women being silent in church are also taken literally"; ${ }^{4}$ they are obeyed and enforced. Also, texts such as 1 Corinthians 11:3 and 1 Timothy 2:9 "are interpreted literally and with universal legislative force, and in so doing exclude females from the centre."15

Pentecostal literal readers do not take into consideration that texts which seem to support the marginalisation of women have a history; they emerge from particular and specific Jewish, Greco-Roman and other patriarchal cultures. Therefore, there is need for readers to read beneath the surface of biblical texts as well as to interrogate the contexts in which texts were produced, what the texts meant then and how they can meaningfully address the $21^{\text {st }}$ century flesh and blood readers of the Bible. Pentecostal literal readers do not care about these contexts, especially when it comes to texts that support patriarchy. Paul's injunctions concerning women are read and applied in the immediate context without any interrogation of his agendas because they confirm and support the existing African dominant ideological frameworks that place women at the margins.

There is inconsistency though in that Pentecostals do not always take the Bible literally in every sense, but when it comes to reading texts that marginalise women, they do so. An interesting conversation took place while I was collecting data in 2011 in Botswana. One Pentecostal male pastor argued that he believed every sentence in Genesis 2:22-24; the second account of the creation story. According to the pastor, It was a fact that Eve was created from Adam's rib and literally a rib was taken from Adam to create Eve. He said that it was a fact that Adam was created first. This fact, according to the pastor, was God's way of demonstrating that men are superior to women. But when I pointed out that Genesis $1: 27$, another creation story, suggests that both men and women were created at the same time, the same respondent then argued that Genesis 1:27 must not be taken literally in every sense because it serves as "an introduction of Genesis 2, which actually tells a complete story." This line of reading and interpreting the Bible among some Pentecostals demon-

\footnotetext{
13 My research assistant, Maria Mpuse and I conducted research on how Pentecostals inhabiting patriarchal spaces in both society and church read biblical texts such as Luke-Acts. We carried out the research from March 2011 to February 2012 among 54 Pentecostals; 51 women and three men. The research was conducted among Pentecostals in three settings in Botswana: an urban, semi urban and a small village. For a detailed discussion of the choice of methods, how the research was conducted, confidentiality, issues of reflexivity and analysis of the data, see Rosinah Mmannana Gabaitse 'Towards an African Pentecostal Feminist Biblical Hermeneutic of Liberation: A Case Study of Interpreting Luke-Acts with Batswana Women.' PhD thesis, University of KwaZulu-Natal, Pietermaritzburg, 2013.

14 Powers, J, “'Your Daughters Shall Prophesy': Pentecostal Hermeneutics and the Empowerment of Women." In The Globalisation of Pentecostalism: A Religion Made to Travel, edited by M Dempster, B Klaus and D. Petersen, 313-337. Irvine: Regnum, 1999:323.

15 Tan-Chow, Pentecostal Theology for the Twenty First Century, 137.
} 
strates that when Pentecostals claim to be literal, they are actually engaging in selective hermeneutics. What emerges here is a clear lack of consistency within Pentecostal frames of interpreting the Bible. Certain texts, especially those commanding women towards submission or a marginal status, are given more 'interpretive power' than others. ${ }^{16}$ In the above instance, Genesis 2:22-24, which seems to be promoting male supremacy, is taken literally in every sense while Genesis $1: 27$, which seems to be suggesting a possibility of an equal status between men and women is not interpreted in a literal sense. Rather, such texts as Genesis 1:27 are downplayed because they are not telling the 'complete story,' the story of subordination of women to male power. My interaction with Pentecostals in Botswana demonstrates that especially some male heads of Pentecostal churches, are willing to fall back on literal and selective reading of texts that grant men power over women in order to secure their patriarchal grip on power, while they abandon the literal readings of texts that seem to promote gender equality and justice. Therefore, Pentecostals enforce literal and uncritical interpretations of certain texts of the Bible so that the subordination and marginalisation of women can be justified and legitimised. The rigidity of Pentecostal hermeneutics in relation to texts that seem to support male dominance and the marginal status of women poses hermeneutical problems and tensions within the hermeneutic itself. For example, Pentecostals hold that the Bible becomes the word of God through the illumination of the Holy Spirit who gives new interpretations of texts, depending on the context. One text can have multiple interpretations "as and when the Spirit wills." However, texts such as Ephesians 5:22 and Genesis 2:22-24 that have traditionally been used to support male power and dominance are interpreted in the same way all the time and in different contexts, be it during Sunday church service or during weddings. The question is, are these texts closed to the illumination of the Holy Spirit? Why are there no new interpretations coming out of these texts? I am yet to hear an interpretation of Ephesians 5:22 coming from places of power instructing women and men to occupy the same status at home, church and society.

\section{Proof Texting and the Marginalisation of Women}

The second aspect of Pentecostal biblical interpretation that is implicated in the marginalisation of women is proof texting. Proof texting refers to the art of using and harmonising a few biblical texts to support any one argument narrowly without considering how those texts relate to the Bible as a whole. Doctrines are supported, proven and disproven through using stand-alone biblical verses. The problem with proof texting is that it ignores the principle of context which demands that the cultural contexts of the Bible be taken into consideration.. According to the principle of context, the Bible should be read, understood and interpreted bearing in mind that it was produced within a particular cultural context very different from contemporary contexts. Moreover, proof texting ignores the fact that Bible stories are connected and can never be understood as stand-alone pieces. That being said, the marginalisation of women within Pentecostal spaces is justified and supported by both men and women through this hermeneutical strategy. Biblical texts such as 1 Corinthians 11:3 and Ephesians 5:22 are used to advance female submission and the headship of men without taking other biblical verses into consideration to balance the argument on the status and position of women in society, church and home. Janet Powers argues that proof texting has led Pentecostals to claim that the subordination of women towards men is

16 McClintock-Fulkerson, M Changing the Subject: Women's Discourse and Feminist Theology Minneapolis: Fortress Press, 1994:255. 
"a creation principle that must be acknowledged by anyone who acknowledges the authority of the Bible.",

The use of proof texting is prevalent among Pentecostals worldwide as demonstrated below. During a debate on the abolition of the Marital Power amendment bill that was introduced in the Botswana Parliament in 2004/2005, one Pentecostal pastor argued against implementing the bill by suggesting that abolishing marital power was against God's principles as stated in the Bible. He argued that God demands women to submit to the authority of a men and he justified his argument by quoting 1 Corinthians 11:3 and Ephesians 5:22-24. ${ }^{18}$ Joshua Adjabeng, a Pentecostal male writing within an African Ghanaian context, instructs women through the apparent biblical support of Ephesians 5:22-24 and I Peter 3:1 that "the lordship of a man, of your husband in the home is a command by God that cannot be compromised."19 Going further up, Wayne Grudem, a Pentecostal male scholar and pastor from the USA, uses 1 Peter 3:1 and Ephesians 5:22-24 to argue that wives should willingly "submit to your husband's authority or leadership in marriage," including submission to 'good or harsh husbands." 20 The three pastors coming from different contexts utilise the same selective hermeneutical strategy, namely, proof texting. Not only do the three male pastors use the same hermeneutical strategy, they also use the same texts: 1 Cor. 11:3; Eph. 5:22-24 and 1 Peter 3:1 to support the submission of women to men and the headship of men. These three Pentecostal pastors use very few scriptural directives to argue that the subjugation of women is divinely commissioned by God. They insist that women should remain at the margins while men occupy the centre on the basis of these few texts. Moreover, proof texting poses a danger to the well-being of women as they are encouraged to submit to both 'good and harsh husbands.' Submitting to harsh husbands has a wide range of meanings and implications. One of the implications may be that women must submit to husbands who are violent, abusive and a danger to their lives. This kind of language and interpretation coming from people with power in the church is dangerous because it legitimises violence. Women are encouraged to accept abuse and still submit to their husbands because the Bible says so. Although the texts do not overtly encourage submission to 'harsh husbands', the interpretations that are derived and given to these texts include submission to harsh husbands. Therefore, proof texting is a problematic and dangerous double-edged hermeneutical strategy; not only is it used to push the status of women to the margins; it also encourages violence against women. Often times married women in abusive and life-denying relationships have been told by their pastors to stay in those relationships through the use of single verses such as Malachi 2:16 which states that "God hates divorce." Had it not been for the Pentecostals' tendency to proof text, Malachi would be read to seek justice for women in abusive relationships, whose only option might be to leave those relationships. Pentecostal women's willingness to stay in life-denying relationships is a direct result of how the Bible is interpreted and the kind of exegetical methods used within Pentecostals churches. ${ }^{21}$ Interpretations and teachings that advance female submission even to harsh husbands within the Pentecostal church translate

\footnotetext{
17 Powers, J, "Pentecostalism 101: Your Daughters Shall Prophesy." In Phillip's Daughters: Women in Pentecostal-Charismatic Leadership, edited by E Alexander and A Yong, 133-151. Eugene, Oregon: Pickwick Publications, 2009:147.

18 Pastor Criticises Abolition of Marital Power' in Mmegi Monitor Monday March 7, 2005:5.9.

19 Adjabeng, J, How To Enjoy Your Marriage, Accra: Olive Publications, 1995:45.

20 Grudem, W 1 Peter, Grand Rapids: Eerdmans, 1988:135.

21 McClintock-Fulkerson Changing the Subject,
} 
into actual tangible practices within homes. Both men and women conduct their lives in the church, society and home according to how the Bible is interpreted and what they have been taught by their church authorities.

Therefore, proof texting which characterises the dominant Pentecostal hermeneutics is one of the reasons for the marginalisation of women within Pentecostal spaces. Gender inequality, violence against women, undermining women and the marginal status of women are legitimised through this selective hermeneutical approach.

\section{Trinity and the Marginalisation of Women}

The third argument that is used to advance the marginalisation of women within Pentecostal churches is a theologically based doctrine of the Trinity. Cheryl Johns, writing within a North American context, states that most Pentecostals believe that God has established a chain of command which is visible even within the Trinity. They argue that within the Trinity there is an established chain of subordination, where God the Son is seen to be subordinate to God the Father. ${ }^{22}$ The relationship of God the Father, God the Son and Holy Spirit is ordered hierarchically. The Trinitarian God is at the top of the hierarchy and is the 'head,' followed by Jesus and the Holy Spirit. Therefore, since Jesus submits to God, the hierarchy between men and women is divinely sanctioned and legitimate. Johns rightly problematises this so-called God-Jesus-Holy Spirit hierarchy. She submits that the argument is used to legitimise the male-female hierarchy as well as to validate teachings that hold that men occupy a higher position in the gender hierarchy and therefore, they must have authority over women. ${ }^{23}$

Pentecostals who believe in the hierarchy within the Trinity advocate hierarchy between people, and specifically hierarchy between men and women. In this hierarchy, men occupy a high status followed by women and children. Moreover, the physiological biological differences between men and women are used to strengthen this belief as well as to advocate gender hierarchies and complementarity. Proponents of this theology argue that God made men and women physiologically different so that they should occupy different statuses and positions. Physiological differences are used to assign and construct roles for men and women Men and women have their positions and roles as heads of households and leaders in the church while women offer supporting and lesser roles. According to this perception and conviction, men have the divine prerogative to rule and command and women must obey. ${ }^{24}$ The performance of gender roles which creates hierarchies between men and women is meant to demonstrate a divinely sanctioned hierarchy and order. I concur with Johns who holds that the appeal to the doctrine of the Trinity is an effort and plot "to keep viable a patriarchal worldview" 25 The appeal is meant to keep male hegemony afloat, as well as to validate the marginalisation of women because there are no ontological differences between men and women, so that there is no reason for advocating gender hierarchy. Similarly, Mary McClintock-Fulkerson has observed that while Pentecostals will not prohibit women from speaking through the Holy Spirit, "submission is couched in the

\footnotetext{
22 Johns, C "Spirited Vestments or Why the Anointing Is Not Enough.” In Philip's Daughters: Women in Pentecostal-Charismatic Leadership, edited by E Alexander and A Yong, 170-184. Eugene, Oregon: Pickwick Publications, 2009:174.

23 Johns, "Spirit Vestments,"“, 176.

24 Johns, "Spirit Vestments,", 176.

25 Johns, "Spirited Vestments," 174-175.
} 
language of gender complementarity." ${ }^{26}$ Unmasking this so-called gender complementarity reveals gender binaries within Pentecostal spaces that are too strict, rigid and not invertible. Appealing to the Trinitarian hierarchy indicates that women will always occupy a marginal status and men will always occupy the centre as long as the hierarchy in the Trinity is not deconstructed.

In my view and that of scholars such as Elizabeth Johnson, the Trinity should be seen as a model of interdependence. For example, Johnson understands the Trinity as a relationship that affirms mutuality, interdependence, equality and community in diversity. ${ }^{27}$ She submits that "the persons of the Trinity are constituted by their relationships to each other; each is unintelligible except as connected with the other." 28 She further submits that "the very essence of God is in relation to ... and relatedness, rather than solitary ego is the heart of all reality." Elevating God above the other two persons of the Trinity is used to justify "social structures of dominance/subordination and an androcentric worldview inimical to the genuine and equal dignity of women." ${ }^{29}$ Therefore, there is no hierarchical ordering in the Trinity as some Pentecostals believe, but rather, the Trinity represents a relationship of coexistence and mutuality. If the Trinity were to be understood in this way, Pentecostal men and women would enjoy relationships of equality as they emulate this relationship of mutuality between the three persons of the Trinity. Pentecostal women would not be marginalised through literal interpretations of texts and through proof texting because men and women would be seen as equals in all spheres of life.

While the Pentecostal church marginalises women through biblical interpretation, there is a power, a character, a force and principle at play within and among Pentecostals, namely, the Holy Spirit, who critiques cultures and interpretations of the Bible that marginalise and oppress people. Pentecostals foreground the experiential aspect of the Holy Spirit so that the Holy Spirit is central to Pentecostal living and existence. The Holy Spirit is perceived as a living power who is experienced by women and men, the power that directs individuals and the Pentecostal community. The Holy Spirit is the power that can convict sinners, critique sin and corrects Pentecostals. Also, the Holy Spirit is the power that calls individuals and communities into existence so that without the Holy Spirit's participation, there can be no authentic Pentecostal community. xPentecostals believe that the Holy Spirit is at the centre of biblical interpretation. According to Pentecostal theology, the Bible "is not of itself the Word of God, it only becomes the Word of God through the continued inspiration of the Holy Spirit," 30 This means that biblical texts and the Holy Spirit are essential authoritative aspects of and are equally placed at the centre of Pentecostal hermeneutics. Since Pentecostalism is not only text-centred, but also in a deep way Holy Spirit-centred, there should not be any room for rigid and literal interpretations of the Bible that marginalise people, especially women. Biblical texts that call women into submission towards men could be interpreted in new ways because the Holy Spirit gives new, life-giving and transformative interpretations of the Bible depending on context. Acts 15 demonstrates how the Holy Spirit was able to transform oppressive cultural practices and offer new interpretations of Scripture that were life-giving to the Gentiles.

\footnotetext{
26 McClintock Fulkerson, Changing the Subject, 255.

27 Johnson, E She Who Is: The Mystery of God in Feminist Theological Discourse. New York: Crossroads, 1994:191-223.

28 Johnson, She Who Is, 216.

29 Johnson, She Who Is, 40.

30 Ellington, S "Pentecostalism and the Authority of Scripture." JPT 9, 1996:16-38.
} 
In Acts 15, some Jewish believers demand that the Gentiles must be circumcised in obedience to the Law of Moses (verse 5). After much deliberation the Jerusalem Council decided not to impose circumcision on the non-Jews because, first, circumcision was a 'yoke' too difficult to bear (verse 10). Second, and most important, "it has seemed good to the Holy Spirit and to us to impose on you no further burden than these essentials" (verse 28. See also Acts 10:45, 11:15-17). By listening to the Holy Spirit, a community of believers was able to dismiss a culture of teaching non-Jews that they could not be saved unless they were circumcised according to the Law of Moses. The Gentiles were given a marginal status unless they circumcised, although this was a Jewish custom, not theirs. This is until the Jerusalem Council listened to the intervention and transformation that the Holy Spirit imposed on them to allow the Gentiles into the congregation without demanding circumcision from them. The community listened and they were able to transcend an established structure of power and authority; the Law of Moses. The Holy Spirit was able to subvert, deny and deconstruct the Law of Moses in relation to circumcision so that Gentiles were not burdened and restricted because of their ethnicity. The imposed marginal status of the Gentiles was denied because of the transformation brought about by the Holy Spirit. If the Holy Spirit was able to legitimise the acceptance of Gentiles as part of the Christian community, the same Holy Spirit should be able to create spaces within the contemporary Pentecostal church where life-denying and oppressive patriarchal cultures are eliminated and denied. Also, once the Holy Spirit is placed at the centre of hermeneutics of the contemporary Pentecostal church and of individuals, the Pentecostal space must necessarily be liberatory because the Holy Spirit is inherently liberatory, empowering and transformative. The Holy Spirit is able to cut across discrimination and restrictions imposed by cultures, laws and practices. If the Pentecostal church can allow the Holy Spirit to truly transform the way the Bible is interpreted in relation to the status of men and women, women will gain a new status, that of truly inhabiting the centre, not the margins. At the moment even if the Holy Spirit offers a "radical levelling of the hierarchies of the world ... Submission to the man ... appears to be a doctrinally held conviction, one not susceptible to direct refutation." 31

Therefore, there is need for the Pentecostal church to allow the Holy Spirit first to critique and convict it of the sin of patriarchy. It is only after the Holy Spirit convicts the church of its sin that the Pentecostal church will allow the Holy Spirit to transform the dominant Pentecostal hermeneutics.

While the liberatory role of the Holy Spirit is not necessarily emphasised and recognised and while Pentecostal women remain at the margins, the Holy Spirit who does not respect any persons, cultures, processes nor boundaries meets women and engages with them even in those margins. It is here that the Spirit gives them a voice. This is why Pentecostal women can be founders of churches, prophetesses and preachers even within cultures that subordinate them to male power. They may be made invisible in those roles because Pentecostal hermeneutics insists that women must be under the authority of a man. However, the Holy Spirit empowers them to perform and shine in those roles, such that Pentecostal women are not cloaked in silence and complete invisibility. The fact that male dominance is promoted and women are relegated to the margins, does not necessarily mean that women are completely without power. The manifestation of the Spirit among Pentecostals in general and women in particular gives women power and recognition and in concrete ways upward mobility is visible and demonstrable Although Pentecostal

31 Fulkerson, Changing the Subject, 259. 
hermeneutics and practices conspire to marginalise women, women can never be without voice because there is another power at work; the Holy Spirit who continuously speaks to and through women.

Finally, the marginalisation and exclusion of women is inimical to the true spirit of Pentecostalism for the simple reason that the Holy Spirit, if listened to, is able to destabilise and threaten patriarchal ideology and prerogatives. This can happen only if the Pentecostal church were to be open to the change and transformation that the Holy Spirit can usher and effect. However, even if the Pentecostal church is not open to embrace women into the centre, the Holy Spirit will continue to critique, unsettle and act against the Pentecostal church for preaching equality between men and women, while in reality they marginalise women and elevate the status of men through an uncritical use and interpretation of the Bible.

\section{Conclusion}

In this paper I have highlighted that the Pentecostal church is a place of exclusion and embrace. There is a sense in which men and women can occupy the centre, yet women are at the periphery and this is largely due to Pentecostal frames of reading and interpreting the Bible. I have also demonstrated that two hermeneutical strategies within Pentecostal hermeneutics, namely, literalist readings of the Bible and proof-texting, together with the theological doctrine and interpretation of Trinity, contribute to the low and marginal status of women within the Pentecostal church. The two hermeneutical strategies, together with the interpretation of the doctrine of Trinity, keep women at the margins as they also perpetuate men's grip on power. However, I have also highlighted the empowering, transformative and liberating work of the Holy Spirit who transcends cultures and practices. Once filled with the Holy Spirit, Pentecostal women are able to transcend gender limitations imposed on them by Pentecostals' biblical interpretations and practices. Even if their statuses remain marginal, the Holy Spirit will continue to unsettle and critique the church until a transformative and liberating way of interpreting the Bible is practiced. It may take time, but we live in hope that one day the transformation of the status of women will occur.

\section{BIBLIOGRAPHY}

Adjabeng, J 1995. How to Enjoy Your Marriage, Accra: Olive Publications.

Alexander, E 2009. "Introduction." In Philip's Daughters: Women in Pentecostal-

Charismatic Leadership, (eds.) Estrelda Alexander and Amos Yong, Eugene,

Oregon: Pickwick Publications.

Archer, KJ 2001. "Early Pentecostal Biblical Interpretation,” JPT 18.

Asamoah-Gyadu, K 1998. "“Fireballs in our Midst”: West Africa Burgeoning Charismatic

Churches and the Pastoral Role of Women," Mission Studies no 296:15-16.

Ellington, S 1996. "Pentecostalism and the Authority of Scripture." JPT 9:16-38).

Grudem, W 1988. 1 Peter. Grand Rapids: Eerdmans.

Johns, C 2009. "Spirited Vestments or Why the Anointing Is Not Enough." In Phillip's Daughters: Women in Pentecostal-Charismatic Leadership, edited by E Alexander and A Yong, (170-184). Eugene, Oregon: Pickwick Publications. 
Johnson, E 1994. She Who Is: The Mystery of God in Feminist Theological Discourse. New York: Crossroads.

Kalu, O 2008. African Pentecostalism: An Introduction. Oxford: Oxford University Press.

Masenya, M 2004. How Worthy is the Woman of Worth? Rereading Proverbs 31:10-31 in African- South Africa. New York; Peter Lang.

Mate, R 2002. "Wombs as God's Laboratories: Pentecostal Discourses on Femininity in Zimbabwe," Africa, Journal of the International African Institute 72, no. 4.

McClintock-Fulkerson, M 1994. Changing the Subject: Women's Discourse and Feminist Theology Minneapolis: Fortress Press.

Nadar, S 2009. “The Bible Says!” Feminism, Hermeneutics and Neo-Pentecostal Challenges' in Journal of Theology for Southern Africa Vol 134.

Powers, JA 1999. “'Your Daughters Shall Prophesy': Pentecostal Hermeneutics and the Empowerment of Women." In The Globalisation of Pentecostalism: A Religion Made To Travel, edited by M Dempster, B Klaus and D Petersen, (313-337). Irvine: Regnum.

Powers, JA 2001. 'Recovering A woman's Head with Prophetic Authority: A Pentecostal Reading of 1 Corinthians 11:3-16' JPT 10.1.

Powers, J 2009. 'Pentecostalism 101: Your Daughters Shall Prophesy.” In Philip's Daughters: Women in Pentecostal-Charismatic Leadership, edited by E Alexander and A Yong, (133-151). Eugene, Oregon: Pickwick Publications.

Tan-Chow, ML 2007. Pentecostal Theology for the Twenty First Century: Engaging with Multi-Faith Singapore. Burlington: Ashgate Publishing Company.

Thomas, C 1994. "Women Pentecostals and the Bible: An Experiment in Pentecostal Hermeneutics." JPT 5:41-56.

Yong, A 2005. The Spirit Poured Out on All Flesh: Pentecostalism and the Possibility of Global of Theology. Michigan: Baker Academic. 